\title{
Unit per Trillion Red Blood Cells
}

National Cancer Institute

\section{Source}

National Cancer Institute. Unit per Trillion Red Blood Cells. NCI Thesaurus. Code

C122228.

An arbitrary unit of substance content expressed in units of biological activity per ten to the twelfth power red blood cells. 